IRA-International Journal of Technology \& Engineering ISSN 2455-4480

Proceedings of the

International Conference on Science \& Engineering for Sustainable Development (2017)

Pg. no. $45-55$

Published by: Institute of Research Advances https://research-advances.org/index.php/IRAJTE

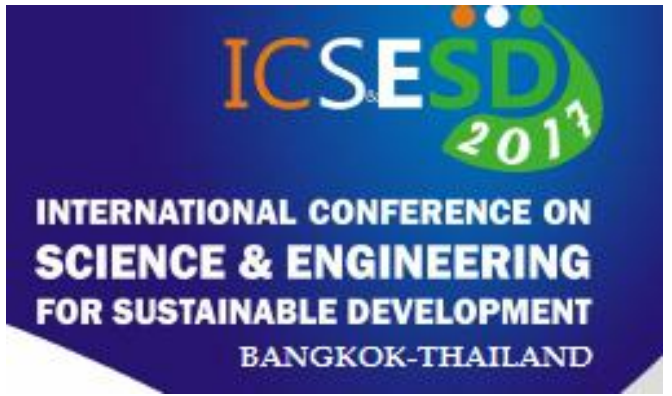

\title{
Analysis of Housing Structures Made From Recycled Plastic
}

\author{
Shreyas S. Gulhane* ${ }^{* 1}$, Sanjay N. Gulhane ${ }^{2}$ \\ ${ }^{* 1}$ Dr. Babasaheb Ambedkar College of Engineering and Research \\ ${ }^{2}$ Director, Nisargika Pvt. Ltd.
}

Type of Review: Originality Check \& Peer Review under the responsibility of the Scientific Committee of the Conference and The Institution of Engineers (India). DOI: http://dx.doi.org/10.21013/jte.ICSESD201705

\section{How to cite this paper:}

Gulhane, S., Gulhane, S. (2017). Analysis of Housing Structures Made From Recycled Plastic. Proceedings of the International Conference on Science \& Engineering for Sustainable Development (2017), 45-55. doi: http://dx.doi.org/10.21013/ite.ICSESD201705

(C) International Conference on Science \& Engineering for Sustainable Development\& The Institution of Engineers (India).

\section{(cc) BY-NC}

This work is licensed under a Creative Commons Attribution-Non Commercial 4.0 International License subject to proper citation to the publication source of the work.

Disclaimer: The conference papers as published by the Institute of Research Advances (IRA) are the views and opinions of their respective authors and are not the views or opinions of the IRA. The IRA disclaims of any harm or loss caused due to the published content to any party. 


\section{ABSTRACT}

Due to rise in unleashed industrial development, our world is now engulfed by solid wastes. In that huge pile of wastes, plastic is one of the prime culprits for degrading our nature. The used plastics (which are not recycled) are either end up in oceans or landfills and continue to create environmental problems. On regular basis, thousands of tonnes of plastic waste is being created all around the world. In some cases, recycling plastic is costlier than using virgin plastic. Hence there is a necessity to create a situation in which adequate price for recycling plastic must come into play. Such type of situation can be created by using plastic as a primary construction material for small houses. The main objective of the study is to show how plastic as a construction material can reduce the stacks of junk plastic piles around the globe. Along with that how it can reduce the time and labor required for construction and also help to reduce the casualties during natural calamities like earthquake and to understand the 'total plastic' construction phenomenon with its advantages and disadvantages.

Today there are some companies which are trying to use plastic as a primary construction material but none of them tried for the total plastic approach. The studies have shown that total plastic approach can eventually reduce the recycling and implementation costs of waste plastic, the time consumed and labor required for plastic recycling. Also to understand the actual practical situation of using plastic houses and required structure and method for shelters made out of such material were analyzed using FEA software. The problems like fireproofing and base development were also studied.

Keywords: Cement, Concrete, Cost, Earthquake, House, Recycled Plastic Lumber (RPL),Recycling, Residential, Waste Plastic.

\section{Introduction}

OUR surrounding is all engulfed with waste plastic. According to a report published in December 2009 by Central Pollution Control Board of India [1],per capita, plastic consumption in India was 6-7 kg per annum and in developed countries, per capita consumption was in the range of 15 to $22 \mathrm{~kg} / \mathrm{annum}$. The report also mentioned that approximately 15,722 metric ton per day (TPD) of plastic waste is generated in India.

The recycling rates are wildly varying across the world based on countries regulations and other factors. Although many people are trying to make recycling figures look higher, but only $22 \%$ of plastic is being recycled all across the world. In 2016, the world witnessed 322 million tonnes of plastic production [2]. Hence, from these figures, it is clear that how much amount is being dumped either in oceans or land. Recycling of plastics as the same product is sometimes not effective financially. To make it effective, we have to use it differently for completely new application. The price of recycling increases due to sorting out plastics and making it chemically perfect for reuse as the same product. However, rather than sorting each type of thermoplastic differently, we can commingle all type of plastics together to form recycled plastic lumbers (RPL).These lumbers can be used as the primary construction material in place of concrete and wood. Also, very few chemical processes are needed in this type of recycling. Hence it makes recycling very easy and cheap. 
Today, there are many working companies with working machines [3] which can effectively clean and form a commingled plastic lumber out of mixed garbage of plastics still none of them are using lumbers for construction of houses.

\section{Material}

Polyethylene Terephthalate (PET), Polypropylene (PP), Poly Vinyl Acetate (PVA), Poly Vinyl Chloride (PVC), Polystyrene (PS), Low Density Polyethylene (LDPE), High Density Polyethylene (HDPE), etc. all these comes in thermoplastic category which contribute to $80 \%$ of total plastic use. Whereas Bakelite, Epoxy, Melamine, Polyester, Polyurethane, Urea - Formaldehyde, etc. comes under thermoset plastics category which contributes $20 \%$ of our plastic use.

For recycling plastics into RPL, thermoplastics are used. These mixed plastic blocks are known as Recycled Plastic Lumbers (RPL). To form these blocks, mixed thermoplastics are not sorted out by their chemistry, they are properly cleaned only. After that, the mixed waste plastics are heated and compressed and then extruded/molded to quickly form whatever shape you want. The products made out of RPL are very long lasting, even companies give 50 years warranty on any RPL product.

Plastic lumbers are $100 \%$ plastics. They are made up by mixing thermoplastics all together at around 400 degree Celsius and then extruded or molded into desired shapes. Vincent et al. [4] have compared some plastic lumbers. The properties of lumber plastics were considered during computer-based analysis of two types of home structures viz., load bearing and framed structure.

The mechanical properties of commingled plastic lumber are mentioned in Table I and properties of masonry wall (constructed using cement and bricks), cement only and, concrete only are mentioned in Table II for the purpose of comparison.

TABLE I

MECHANICAL PROPERTIES OF RECYCLED PLASTIC LUMBER TAKEN FOR COMPUTER-BASED SIMULATION

\begin{tabular}{ll}
\hline \hline Material Property & Value \\
\hline Specific density & 0.86 \\
Compressive strength & $25.88 \mathrm{MPa}$ \\
Ultimate tensile strength & $10.15 \mathrm{MPa}$ \\
Modulus of elasticity & $965.26 \mathrm{MPa}$ \\
& \\
\hline \hline
\end{tabular}

TABLE II

MECHANICAL PROPERTIES OF CEMENT, BRICKS, AND MASONRY WALL

\begin{tabular}{ll}
\hline \hline Material Property & Value \\
\hline Density of cement and lime & $2400 \mathrm{~kg} / \mathrm{m}^{3}$ \\
Density of bricks & $1920 \mathrm{~kg} / \mathrm{m}^{3}$ \\
Compressive strength of masonry wall & $1.8-2.9 \mathrm{MPa}$ \\
Compressive strength of residential concrete & $17-28 \mathrm{MPa}$
\end{tabular}


Modulus of elasticity of masonry wall

2.52-3.32 GPa

Modulus of elasticity of residential concrete

45-85 GPa

The text should be organized into logical parts or sections. Headings and subheadings should appear throughout the paper to divide the subject matter to emphasize the major elements. These headings assist the reader in following the trend of thought and in forming a mental picture of the points of importance. Parts or sections may be numbered, if desired, but paragraphs should not be numbered.

\section{Methodology}

A. Design and Analysis of house and living room

To test whether the commingled plastic can sustain the loads mentioned according to IS-875 for residential buildings, some CAD models were made by considering the general public living area in India. Such housings structures were developed using two methods viz., load bearing structure and other is framed structure. In load bearing structures the walls of the building are subjected to transfer the load to ground. In framed structures, loads are supported using the outer frame.

All these structures were designed only for residential dwelling houses. Load bearing capacity is designed according to that consideration only. According to IS-875[5], [6], [7], various loads on the building were implemented for computer-based analysis. The loads on the building are mentioned in Table-III.

TABLE III

VARIOUS LOADS ON RESIDENTIAL DWELLING HOUSES

\begin{tabular}{lll}
\hline \hline Residential Dwelling Houses & Uniformly Distributed LoadkN/m & Concentrated Load $\mathrm{kN}$ \\
\hline All rooms and kitchen & 2.0 & 1.8 \\
Toilet and bathroom & 2.0 & -- \\
Corridors, passages, staircases including & 3.0 & 4.5 \\
fire escapes and store rooms & & \\
Balconies & 3.0 & $\begin{array}{l}1.5 \text { per meter run } \\
\text { concentrated at the outer } \\
\end{array}$ \\
& & edge \\
Wind load & 4.0 & -- \\
Snow load & 2.0 & -- \\
& & \\
\hline \hline
\end{tabular}

The first model was considered for the complete housing of general public. According to a report in Times of India, the housing area for average Indian is $103 \mathrm{ft}^{2}$ per person in rural areas and $117 \mathrm{ft}^{2}$ per person in urban areas [8].Hence the area of the base was selected around $930 \mathrm{ft}^{2}$ area for the base. After running the analysis for this load bearing structure, the analysis showed that maximum stresses were coming on the largest unsupported area with total deflection of $18 \mathrm{~cm}$. This area was the area above living 
room. Hence model is then reduced to small area considering it as the living room so that it will expose maximum unsupported area over the top.

$12 \mathrm{~m} \times 7.2 \mathrm{~m}$ (approx. $930 \mathrm{ft}^{2}$ ) was the base area of the house with the same area of $1^{\text {st }}$-floor. In this design, the walls were hollow but solid at the middle section which was preferred for load bearing with less plastic mass. The loads applied are mentioned in the table following the Indian Standards.

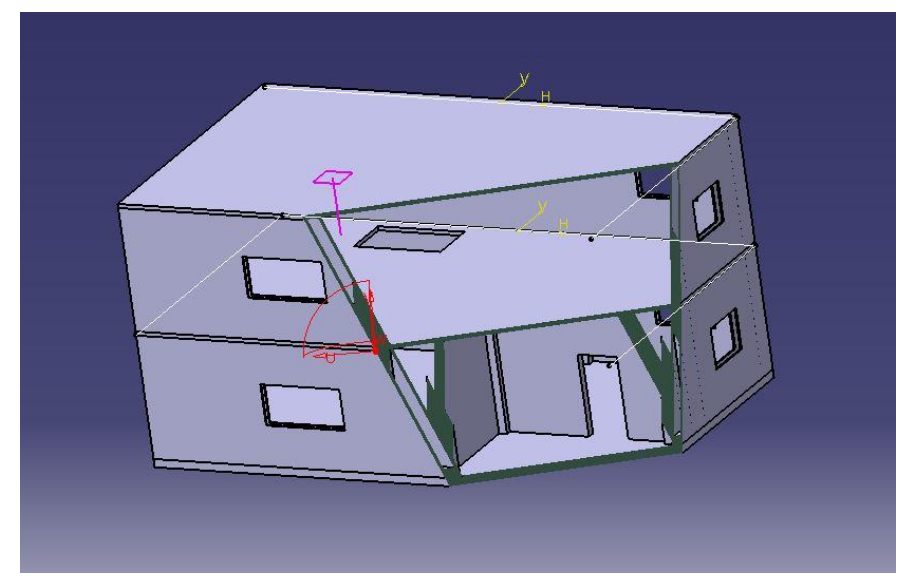

Fig. 1. A cut section view of a two storied house with the general living area in India.

The fixed support was given to base during analysis and contacts between the walls and slabs was the bonded type. According to Indian standard and safety, the load applied here was $3 \mathrm{kN} / \mathrm{m}^{2}$ with $4.5 \mathrm{kN}$ concentrated load at the corner of the structure. Walls of small rooms underneath the first floor bore load effectively. But the area of the living room was large and hence no effective load bearing was being performed. Under that circumstance, the slab took the whole load. The static structural analysis of the building demonstrated in Fig. 2. clearly shows that the total deformation in the slab between $1^{\text {st }}$ floor and the ground floor is huge i.e. $18 \mathrm{~cm}$. The thickness of the $1^{\text {st }}$-floor base is $10 \mathrm{~cm}$. If the thickness is doubled then the total deformation will definitely reduce but a large quantity of material will need to sustain under applied loads. Hence then the study was reduced to living area only to try various designs of the slab.

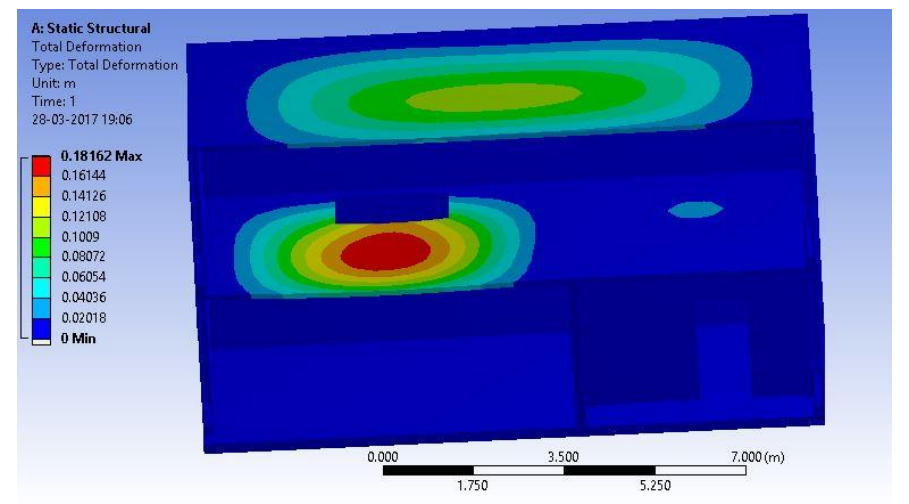

Fig. 2. A cut section view of the house after doing theanalysis. On the slab between ground and first floor, above wide unsupported area, the red zone states that the deformation is $18 \mathrm{~cm}$. 
The area of the living room is $7.4 \mathrm{~m} \times 5.6 \mathrm{~m}\left(445 \mathrm{ft}^{2}\right)$. To understand design effectiveness with minimal material, the analysis with similar loads are applied to both load bearing and frame bearing models of the living room. Table IV and Table V show the difference between load bearing structure and framed structure with computer-based analysis results.

TABLE IV

DESIGN AND ANALYSIS IMAGES \& VALUES FOR LOAD BEARING STRUCTURE

Title and Properties
Cut section view of load bearing design of the living
room. The walls are hollow but solid at middle and
comparatively thick in this model for load bearing.
The wall is $5 \mathrm{~cm}$ thick at each side with $10 \mathrm{~cm}$ hollow
gap and overall $20 \mathrm{~cm}$ thick at solid sections. Slab is
also $10 \mathrm{~cm}$ thick.

Images and values

Stress distribution in the living room in load bearing design

Maximum stresses induced

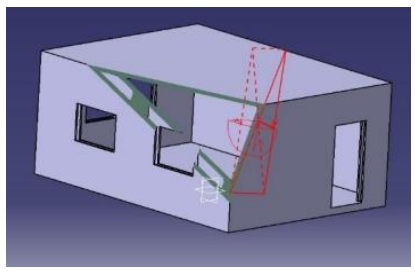
also $10 \mathrm{~cm}$ thick.

Total deformation

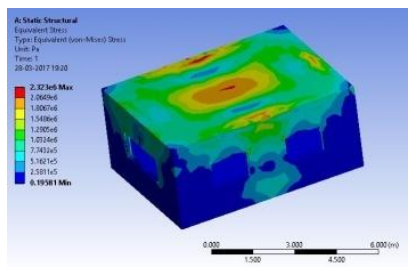

Volume

$2.32 \mathrm{MPa}$

Mass

$7.5 \mathrm{~cm}$

$20.48 \mathrm{~m}^{3}$

$17612.8 \mathrm{~kg}$

TABLE V

DESIGN AND ANALYSIS IMAGES \& VALUES FOR FRAMED STRUCTURE

Title and Properties Images and values

Cut section view of framed structure design of the living room. In this design the beams and columns are hollow. Also, the wall and slab are hollow with straight ribs for extra support (Overall thickness of the material is $1 \mathrm{~cm}$ for

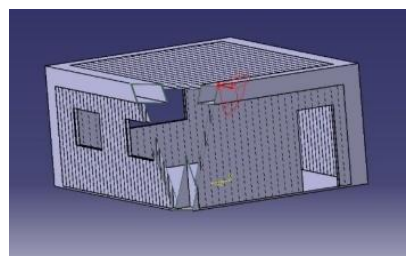
walls \& slabs and $3 \mathrm{~cm}$ for beams \& columns). 
Stress distribution in the living room in framed structure design

Maximum stresses induced

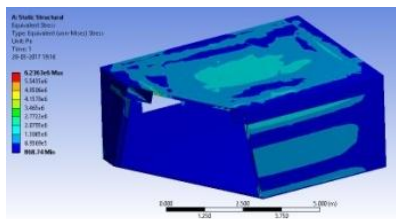

Total deformation

$6.23 \mathrm{MPa}$

Volume

$5.5 \mathrm{~cm}$

Mass

$6.694 \mathrm{~m}^{3}$

$5756.8 \mathrm{~kg}$

B. Design and Analysis of slabs only

Some designs of slabs were tried to get minimum deformation, but after running this analysis it was found that more study will need in this section. Due to low elasticity modulus, the deformations found to be excessive for two storied buildings. Table VI and table VII show the deformation in each design of slab.

TABLE VI

DESIGN AND ANALYSIS IMAGE \& VALUES FOR SLAB WITH STRAIGHT RIBS

\begin{tabular}{ll}
\hline \hline Title and Properties & Images and values \\
\hline A slab of straight ribs (rectangular hollows) & \\
& $6.4 \mathrm{~m} \mathrm{x} 4.6 \mathrm{~m} \mathrm{x} 0.12 \mathrm{~m}$ \\
Overall dimensions & $2.00 \mathrm{~cm}(\mathrm{constant})$ \\
Material thickness & $3.28 \mathrm{~cm}$ \\
Total deformation & $3.48 \mathrm{MPa}$ \\
Maximum stress & \\
\hline \hline
\end{tabular}


DESIGN AND ANALYSIS IMAGE \& VALUES FOR SLAB WITH TRIANGULAR PATTERN RIBS

\begin{tabular}{ll}
\hline \hline Title and Properties & Images and values \\
A slab of triangular ribs (triangular hollows) & \\
Overall dimensions & $6.4 \mathrm{~m} \mathrm{x} 4.6 \mathrm{~m} \mathrm{x} 0.12 \mathrm{~m}$ \\
Material thickness & $2.00 \mathrm{~cm}($ constant $)$ \\
Total deformation & $2.56 \mathrm{~cm}$ \\
Maximum stress & $3.32 \mathrm{MPa}$ \\
\end{tabular}

\section{Thermal Performance}

Problems regarding maintaining the temperature of residential places are huge. In many parts of the world, during summer season concrete in masonry structures absorb too much heat and then emit it continuously throughout the rest of 24-hour cycle after dusk. The result of such absorption rate causes irritation in the day to day living. Hence material with low solar absorptivity coefficient can keep the houses cool during summer. Plastic is one of them, it does not absorb radiation as that of concrete do. The absorptivity of the concrete is around 0.6 and absorptivity of plastics is around 0.3 (without any dye or color addition).

Also, the thermal conductivity of plastic lumber is $0.3317 \mathrm{~W} / \mathrm{m} \cdot \mathrm{K}$ and thermal conductivity of air is $0.0271 \mathrm{~W} / \mathrm{m} \cdot \mathrm{K}$ at $40^{\circ} \mathrm{C}$. Whereas, the thermal conductivity of cement and concrete is 0.72 and that of bricks is 1.3. Hence, from these values, it is clear that plastics can perform better to keep inside temperature of building lower in summer and higher in winter than surrounding in comparison to masonry structures.

One of the main reasons that plastics generally avoided for construction is their flammability. They can catch flame at around $224^{\circ} \mathrm{C}$. However, Nowadays almost every company add flame retardant to recycled plastic lumbers. Hence, it does not catch fire easily. But, the fire safety must be the utmost priority. To solve fire problem permanently, the addition of gypsum board from inside and outside of the house can prevent fire just like bricks with Class 1 fire spread retardingability. The cost of such boards is around INR 60 to 120 per $\mathrm{m}^{2}$. Therefore, it does not add much cost to bolt gypsum boards on to the recycled plastic lumber walls. 


\section{Earthquake Scenario}

The high frequency with short time span earthquakes usually destroys small houses whereas low frequency but long lasting earthquakes can destroy the big buildings [9]. In both cases, people do die due to building collapse. Ideally, our shelter should always protect us in the case of any calamities. But instead of protecting, our masonry constructions tend to collapse and kill thousands of people if earthquakes happen. For example, 1,60,000 to 3,16,000 people died in a 7 magnitude earthquake in 2010 in Haiti region and almost all the people died in their home or working zone. Since 2001, seven such incidents had happened in which casualties were near 10,000 or above it. Few were totally devastating like Haiti region earthquake. The main reason of death was heavy slabs and walls collapsing on people. Although these plastics recycled lumber houses are not tested for earthquake scenario for their sustaining ability, but the density of wall and beam/column are around $182 \mathrm{~kg} / \mathrm{m} 3$ and $195 \mathrm{~kg} / \mathrm{m} 3$ respectively because of hollow designs. It is far lower against density of cement which is $1506 \mathrm{~kg} / \mathrm{m}^{3}$, gravel mixed concrete $=2400 \mathrm{~kg} / \mathrm{m}^{3}$ and, common red brick $=1920 \mathrm{~kg} / \mathrm{m}^{3}$. Hence if RPL homes crumble during an earthquake, it should not hit people with totally deadly weight in comparison to masonry houses.

\section{Cost Estimation}

After comparing commingled plastic lumber prices on various websites, it is found that it costs around 8.9 rupees per $\mathrm{kg}$. The area of framed structure is around $445 \mathrm{ft}^{2}$. Total weight for construction using RPL in this area came at $5757 \mathrm{~kg}$. Hence it should cost around INR 51,237 without any interior or exterior decoration or utility added to it. Fastening agents and gypsum boards may add around INR 10,000 to 20,000 to it.

The current prices of masonry construction in India for residential dwelling houses are INR 600 per $\mathrm{ft}^{2}$ of construction without any interior or exterior decoration. The usual prices in cities are higher, near about INR 1000 per $\mathrm{ft}^{2}$ of construction. Hence for constructing $445 \mathrm{ft}^{2}$ with INR 600 per $\mathrm{ft}^{2}$, it will cost around INR 2,67,000. Whereas INR $600{\mathrm{per} \mathrm{ft}^{2}}^{2}$ is the cheapest rate of construction without agood quality of raw ingredients. The values clearly signify that the masonry construction should cost at least 4 folds than recycled plastic lumber construction.

Wooden houses are highly used in western societies. Lot many trees are being cut every day for housing purpose. If RPL is used for housing purpose instead of wood, then it will benefit monetarily to the user. Although purchase cost of RPL is 2-3 times costlier than wood, but running cost of RPL is negligible with 50 years manufacturer's warranty. Hence with time wood purchase plus running cost takes over the RPL purchase plus running cost.

It indicates that if RPL costs are cheaper than other products in market then the cost of RPL can be raised a bit with an adequate amount to ensure high plastic recycling rates across the world. 


\section{Environmental Analysis}

Today, in this changing world the construction is increasing very rapidly. Almost every city is expanding exponentially. Due to this expansion habitats are continuously changing and this change is bringing many problems with it. As we are growing, our infrastructural and housing needs are growing continuously. On a good land if we construct using cement then that land is wasted environmentally. It becomes completely useless for vegetation purpose. The problem stated here is not the only one, there are many. If we consider cement production, the $\mathrm{CO}_{2}$ released from fuel burned during the cement production and also from chemical reactions contribute to total $5 \%$ of global $\mathrm{CO}_{2}$ manmade release. Almost $900 \mathrm{~kg} \mathrm{of} \mathrm{CO}_{2}$ is released per tonne of cement production.

On the other hand, the plastics are causing serious problem to our environment. Landfills and ocean dumping of plastics infiltrate the food chain and poison ecosystems. Lot many animals, fishes, birds, etc. fail to excrete eaten plastics and compromise their well-functioning digestive system.

Hence rather than using cement, concrete, and bricks as a construction material for single storied buildings, if we use RPL as the construction material then recycling of plastic will maximize due to increase in the cost of recyclable plastics as mentioned in cost estimation section. Each small house can consume at least 30 to 40 thousand kilos of plastics. If designs are improved then the plastic consumption might reduce and a number of houses can be increased with the same quantity of available waste plastic. Each city can have such plants to make housing panels like jigsaw puzzles so that houses can be assembled easily and can be made in several days. It will also help to reduce the energy required in terms of fossil fuel for transportation of bricks, cement, sand and excavation of raw materials.

\section{Conclusion}

These plastic homes shall be very beneficial for limiting the plastic waste going up for landfilling and ocean dumping. It will also help to bring good prices to waste plastic collection which ultimately increases the waste plastic collection amount. There is also a chance of an increase in employment, as new industry will form out of this.

Houses made up of recycled plastic have other benefits like quick housing with very low cost. Anyone with needs of the quick and cheap house can buy this. Further design optimization can make it cheaper than ever before. The complete assembly of houses can be achieved in several days. Earthquake prone areas should have such type of houses on priority because the density of material is low, hence if collapsed it will not hit people deadly. Also, if broken they can be reassembled. This will save lives as well as money required for rebuilding.

The computer-based analysis has shown that maximum stresses came inside the structure as $2.32 \mathrm{MPa}$ for load bearing structure and 6.32 $\mathrm{MPa}, 3.48 \mathrm{MPa}$, and 3.32 $\mathrm{MPa}$ for framed structure. Hence Recycled Plastic Lumber can sustain stresses induced due to compression (25.88 MPa) and tension (10.15 MPa) both. The houses were tested for imposed, the wind, and snow loading in which total deformation of a slab of the first floor was around $7.5 \mathrm{~cm}$ for load-bearing structure and $5.5 \mathrm{~cm}, 3.28 \mathrm{~cm}$, and $2.56 \mathrm{~cm}$ for framed structures. This shows that the houses will be safe for a living but due to less elasticity modulus large deformations are coming. Hence it implies that these houses cannot be built above the ground floor 
without any further frame development or without using any other material for the slab. However, products like a Thermo-polymerised rock (TPR) [10] can be used for slab only to build further stories over the ground floor. TPR is a synthetic concrete manufactured from reclaimed minerals and hard recyclable plastics. It is 6 times as strong as equivalent (Gen 3) concrete and 30\% lighter in weight. This will increase the cost but it will be beneficial for floor increment.

\section{References}

[1] Dr. K. Pal, “Assessment of Plastic Wasteand Its Management at Airports and Railway Stations in Delhi," Abbrev. CPCB, Delhi., India, Dec 2009.

[2] Plastics - the Facts 2016. PlasticEurope. [online]. Available: http://www.plasticseurope.org/Document/plastics---the-facts-2016-

15787.aspx ?Page $=$ DOCUMENT \&FolID $=2$

[3] http://american-plasticlumber.com/lumber/industrial/technical-data/

[4] T. Li, M. S. Silverstein, A. Hiltner, and E. Baer. (1994). Mechanical Properties of Commingled Plastic from RecycledPolyethylene and Polystyrene. Journal of Applied Polymer Science, Vol. 52. pp. 315-327 (1994). Available: http://onlinelibrary.wiley.com/doi/10.1002/app.1994.070520216/full

[5] Code of practicedesign loads (other thanforearthquake) for buildings and structures part-2 Imposed loads, IS 875-2, 1987.

[6] Code of practicedesign loads (other thanforearthquake) for buildings and structures part-3 Wind loads, IS 875-3, 1987.

[7] Code of practicedesign loads (other thanforearthquake) for buildings and structures part-4 Snow loads, IS 875-4, 1987.

[8] Thakur, Atul (25 November 2008). "33\% of Indians live in less space than US prisoners". The Times of India.

[9] "Buildings and Earthquakes-Which stands? Which falls?" IRIS and University of Portland, Jan $12,2010$.

[10] www.affresol.com

[11] R.t Siddique, J. Khatib, I. Kaur. (2007, November).Use of recycled plastic in concrete: A review. ScienceDirect Waste Management..pp. 1836-1852. Available: https://www.researchgate.net/publication/5865682_Use_of_recycled_plastic_in_concrete_A_review.

[12] V. T. Breslin, U. Senturk, C. C. Berndt. (1998, May). Long-term engineering properties of recycledplastic lumber used in pier construction. Elsevier Resources, Conservation, and Recycling. Vol. $23 . \quad$ pp. 244-257.Available: http://www.sciencedirect.com/science/article/pii/S092134499800024X

[13] (2003, January). RecycledPlasticLumber. EPIC \& CSR. [online]. Available: http://citeseerx.ist.psu.edu/viewdoc/download?doi=10.1.1.200.2614\&rep=rep1\&type=pdf

[14] Ž. Radovanovic, R. Sindic, Grebovic, S. Dimovska, N. Serdar, N.Vatin, V.Murgul, "The Mechanical Properties of Masonry Walls - Analysis of the TestResults," in Proc. SPbUCEMF, 2015, pp. 866-873

[15] https://www.markstaar.com/Recycled-Plastic-Lumber/KING-Plastic-Recycled-LandscapeTimbers-and-Railroad-Ties/

[16] https://www.quora.com/What-is-a-good-way-to-estimate-the-cost-of-construction-for-a-residentialhouse-in-Hyderabad-India 